\title{
Addition to the Distributional Record of Ageniella (Neotumagenia) amazonica Fernández, 1998 (Hymenoptera: Pompilidae) and Establishment of a Neotype
}

\author{
Cecilia Waichert and James P. Pitts \\ Department of Biology, Utah State University, Logan, UT 84322, USA \\ Correspondence should be addressed to Cecilia Waichert, cwaichert@gmail.com \\ Received 12 January 2012; Accepted 2 March 2012 \\ Academic Editor: David Roubik
}

Copyright (C) 2012 C. Waichert and J. P. Pitts. This is an open access article distributed under the Creative Commons Attribution License, which permits unrestricted use, distribution, and reproduction in any medium, provided the original work is properly cited.

Ageniella is a diverse and poorly studied genus in Ageniellini (Pompilidae: Pepsinae). It is composed of nine subgenera with four being endemic to the Neotropical region. Herein, the second record in the literature for the subgenus Neotumagenia is documented, the distribution range is extended, and a neotype is established. This is the first record of this subgenus in Brazil.

\section{Introduction}

Ageniella Banks is the second most diverse genus in Ageniellini with about 110 valid species and nine subgenera. The genus is found throughout the New World [1], from Canada to Argentina, but it is most diverse in the Neotropical region [2].

Ageniella wasps are highly variable morphologically. Body size in males, for example, varies from some having a body length of $<2.0 \mathrm{~mm}$ to longer than $15.0 \mathrm{~mm}$ [3]. Coloration of the species is also variable. Species can have all of the integument or certain parts areas red, orange, black, or blue metallic, with or without long setae. Taxonomists working on Ageniella struggle to determine diagnostic characters for the genus and its subgenera. Shimizu [4] performed a phylogenetic analysis of the genus using morphological characters but did not recover any synapomorphic characters, or a monophyletic Ageniella. The variation in the genus is not only remarkable within subgenera, but also within species as well.

The last subgenus added to Ageniella was Neotumagenia Fernández [5]. This subgenus is monotypic and is restricted to the Neotropics. Ageniella (Neotumagenia) amazonica Fernández was described from Colombia based on a single female exemplar. This species is unique within Ageniella by having a large, grooved, polished swelling on the front, just above each torulus, and stout legs. The biology of A. amazonica is unknown, and the subgenus and species are based only on the female. The holotype of Ageniella (Neotumagenia) amazonica is currently lost (F. Fernández pers. com.).

Herein, we establish a Neotype for the species, provide illustrations, and extend the distributional range of the taxon to Brazil.

\section{Material and Methods}

The studied material was derived from a loan from the Museu Paranaense Emílio Goeldi (MPEG), Belém, Pará, Brazil. Besides MPEG, two specimens will be deposited in different collections, as designated in text: Entomological Museum of Utah State University (EMUS), Logan, Utah, USA; Instituto de Ciencias Naturales-Museo de Historia Naturales (UNCB), Universidad Nacional de Colombia, Bogotá, Colombia.

Abbreviations used in the descriptions are the same as those used by Fernández [5] and Wasbauer and Kimsey [6]. They are defined as follows: FD $=$ facial distance; LA3 = length of third antennal segment; MID = middle interocular distance; $\mathrm{OOL}=$ ocellocular length $; \mathrm{POL}=$ postocellar length; TFD = transfacial distance; UID = upper interocular 
distance; WA3 = width of third antennal segment. Measurements of the clypeus are as follows: WC, width of clypeus, measured from the widest points; LC, highest length of clypeus.

Collection locality of the specimens was obtained from the literature (holotype) and from the specimen labels (new records). These data were used to obtain the geographical coordinates with Google Earth to construct the distribution map with ArcView version 9 software by ESRI [7].

\section{Results and Discussion}

3.1. Taxonomy and New Records. Subgenus Neotumagenia Fernández.

Type-Species. Ageniella (Neotumagenia) amazonica Fernández, 1998. Caldasia 20:1-4 [f\#, COLOMBIA (lost)]. Original designation.

Ageniella (Neotumagenia) amazonica Fernández, 1998 (Figures 1(a) and 1(b)).

Neotype. 1 female. Brasil, Pará, Serra Norte, N1-Mata, 28-31.x.1985, Armadilha $1.6 \mathrm{~m}$ suspensa, $6^{\circ} 00^{\prime} 25^{\prime \prime} \mathrm{S}$ $50^{\circ} 18^{\prime} 32^{\prime \prime} \mathrm{W}, \mathrm{N}$. Bittencourt [col.] (MPEG no. HYM 11005855).

Diagnosis. This species can be recognized from other Ageniella by the following combination of characters: the integument is black on head and metasoma, orange with black ventrally on mesosoma (Figure 1(a)); the face has two large protuberances (Figure 1(b)), and it is covered by silver scale-setae, except by the protuberances, which are shining; the clypeus is convex, with apical margin slightly prolonged; the fore wing is hyaline with a dark band.

Measurements ( $\mathrm{mm}$ ) and Ratios. Body length: 7.72; forewing 6.59; maximum wing width 1.80. FD: 1.69; MID: 1.18; UID: 0.78; LID: 0.94; TFD: 2.00; OOL: 0.19; POL: 0.08; WC: 0.98; LC: 0.47; WA3 0.33X LA3.

\subsection{Examined Material}

1 Female. Brasil, Pará, Serra Norte, Serraria, 20-23.vi.1986, armadilha $1.6 \mathrm{~m}$ suspensa, $5^{\circ} 58^{\prime} 37^{\prime \prime} \mathrm{S} 50^{\circ} 19^{\prime} 43^{\prime \prime} \mathrm{W}$, J. Dias [col.] (MPEG no. HYM 11006147: deposited in UNCB);

1 Female. Brasil, Pará, Juruti, Beneficiamento, Malaise 4, 1525.vi.2009, $2^{\circ} 31^{\prime} 29^{\prime \prime} \mathrm{S} 56^{\circ} 11^{\prime} 13^{\prime \prime} \mathrm{W}$ (MPGE);

1 Female. Brasil, Amazonas, Marãa, R. Japurá, Maguari, 11-17.x.1988, Armadilha $1.6 \mathrm{~m}$ suspensa, $1^{\circ} 49^{\prime} 28^{\prime \prime} \mathrm{S}$ $65^{\circ} 21^{\prime} 28^{\prime \prime} \mathrm{W}$, J. Dias [col.] (MPGE \# HYM 11090903: deposited in EMUS).

The Neotype (Figures 1(a) and 1(b)) does not vary from the original description, and there is no notable variation between studied specimens.

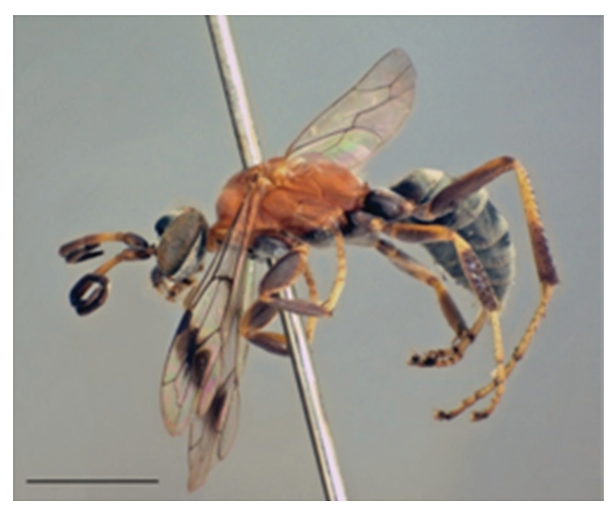

(a)

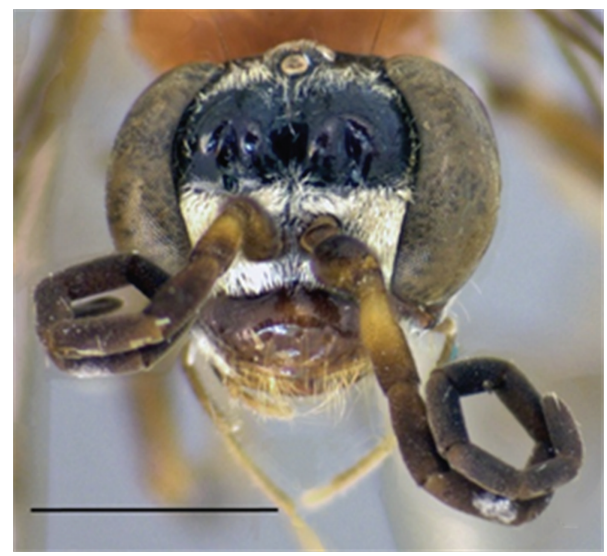

(b)

Figure 1: Neotype of Ageniella (Neotumagenia) amazonica. (a) Habitus, lateral view. Scale $=2.4 \mathrm{~mm}$. (b) Head, frontal view. Scale = $1.29 \mathrm{~mm}$.

The frontal processes (Figure 1(b)) present in this species are intriguing, but other examples of this feature exist in the family (e.g., Auplopus iris (Banks)) and even in the genus Ageniella. In Ageniella, these processes are present also in Ageniella (Cyrtagenia) fallax Arlé, but in this taxon, they are not as large or as prominent as the shiny protuberances found in A. amazonica. Other genera of Pompilidae, such as some African Cryptocheilus reported by Arnold [8], have frontal protuberance as well. Auplopus iris (Banks) has very similar head morphology, differing only by having silver scale setae in small areas of inner face of the eyes, and the clypeus is more sharpened medially and convex; while A. amazonica has setae covering most of the face, but the protuberances and the apical margin of clypeus are less prolonged. Ageniella amazonica has the frontal processes acute, invaginated, and asetose, which has an obvious groove for housing the antenna. Perhaps the frontal processes in $A$. amazonica are related to antennal support while female is hunting for a spider or building a nest, but this is conjecture, and the function of these processes remains a mystery.

Ageniella amazonica also differs from the other species of Ageniella by having stout front legs. Many species of Ageniella dig nests on ground using the front legs [9]. It is possible that these females use the head to close the burrow 


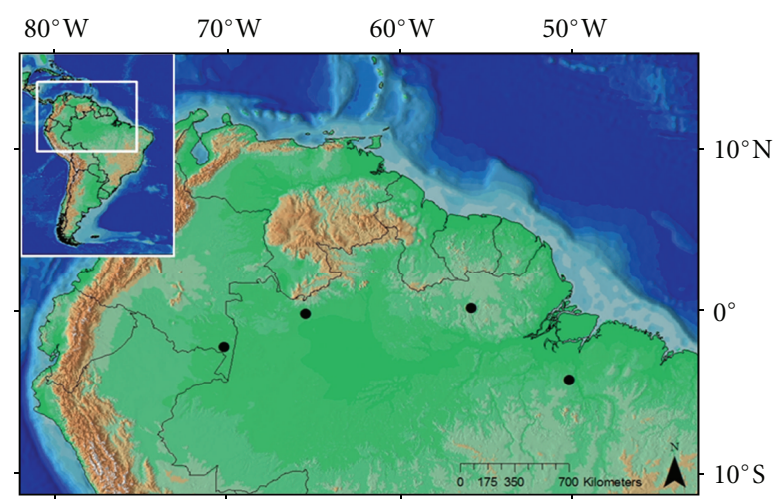

Figure 2: Distributional map of Ageniella (Neotumagenia) amazonica.

dug and pack the soil. In this case, the stout femora of the front legs, the polished head with scale-like setae, and frontal protuberances may be adaptations to this behavior.

Unfortunately, the Neotropical fauna of Ageniella is taxonomically unknown and poorly studied. The species described for the Neotropics lack comprehensible descriptions, keys, and illustration. Moreover, the current outdated taxonomy of the group impedes ecological, behavioral, and biogeographic studies. The last Neotropical survey was made by Evans [10], who studied the Ageniellini of the Neotropics, provided a key for females to subgenera, and corrected taxonomic problems created by Haupt.

This study represents the first record of A. amazonica for Brazil. It was previously only known from the type locality $[5,11]$. Our study indicates that this species is restricted to the Amazon Forest (Figure 2), and it is probably widespread through it. Yearly precipitation in the occurrence area varies from $1600 \mathrm{~mm}$ to $3600 \mathrm{~mm}$; regional variation in climate is homogenous and is the least variable in Brazil [12].

Finally, the designation of a neotype and the record of new specimens are significant to the taxonomy of Ageniella, contributing to enrich distributional and morphologic information regarding this New World taxon.

\section{Acknowledgments}

The authors are thankful to W. Hanson for funding the first author's trip to visit several Brazilian collections in 2010, Orlando T. Silveira (MPEG) for loaning valuable specimens, Celso O. Azevedo (UFES) and Rodrigo B. Ferreira for support offered during the trip and helping with ArcGIS, Fernando Fernández for sharing personal information, and Kevin Williams for helping sorting the specimens. This work was supported by the National Science Foundation award DEB-0743763 to JPP and CVDvD, and by the Utah Agricultural Experiment Station, Utah State UAES no. 8395.
Bulletin, Smithsonian Institution, Washington, DC, USA, 1957.

[2] M. S. Wasbauer, "Pompilidae," in The Hymenoptera of Costa Rica, P. E. Hanson and I. D. Gauld, Eds., pp. 522-539, Oxford University Press, New York, NY, USA, 1995.

[3] H. E. Evans, "Spider wasps of Colorado (Hymenoptera, Pompilidae): An annotated checklist," Great Basin Naturalist, vol. 57, no. 3, pp. 189-197, 1997.

[4] A. Shimizu, M. Wasbauer, and Y. Takami, "Phylogeny and the evolution of nesting behaviour in the tribe Ageniellini (Insecta: Hymenoptera: Pompilidae)," Zoological Journal of the Linnean Society, vol. 160, no. 1, pp. 88-117, 2010.

[5] F. C. Fernández, "Nuevo subgenero y nueva especie de avispa cazadora de arañas (Hymenoptera: Pompilidae: Ageniellini: Ageniella) de Colombia," Caldasia, vol. 20, no. 1, pp. 1-4, 1998.

[6] M. S. Wasbauer and L. S. Kimsey, California Spider Wasps of the Subfamily Pompilinae (Hymenoptera: Pompilidae), vol. 26 of Bulletin of the California Insect Survey, University of California Press, Berkeley, Calif, USA, 1985.

[7] ESRI, ArcView 9.3, ESRI, Redlands, Calif, USA, 2008.

[8] G. Arnold, "The Psammocharidae of the Ethiopian region," Annals of the Transvaal Museum, vol. 14, pp. 284-396, 1932.

[9] H. E. Evans and A. Shimizu, "Further notes on the nesting behaviour of Ageniellini (Insecta: Hymenoptera: Pompilidae)," Journal of Natural History, vol. 32, no. 9, pp. 1411-1412, 1998.

[10] H. E. Evans, "Studies on Neotropical Pompilidae (Hymenoptera) IX. The genera of Auplopodini," Psyche, vol. 80, pp. 212226, 1973.

[11] F. C. Fernández, "Avispas cazadoras de arañas (Hymenoptera, Pompilidae) da la región Neotropical," Biota Colombiana, vol. 1, no. 001, pp. 3-24, 2000.

[12] A. Ab'Saber, Os Domínios da Natureza no Brasil: Potencialidades Paisagísticas, Ateliê Editorial, São Paulo, Brazil, 2003.

\section{References}

[1] H. Townes, Nearctic Wasps of the Subfamilies Pepsinae and Ceropalinae, vol. 209 of United States National Museum 

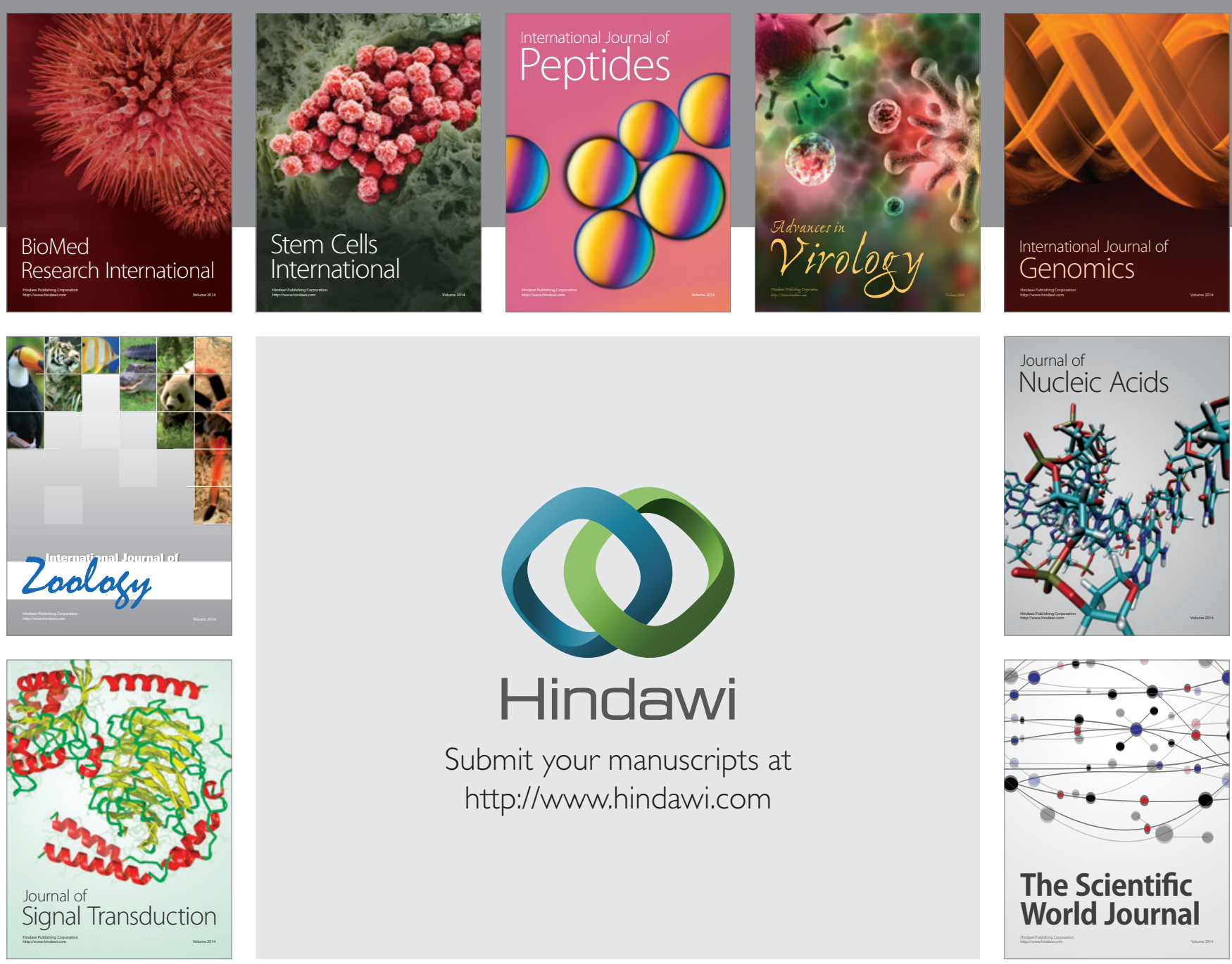

Submit your manuscripts at

http://www.hindawi.com
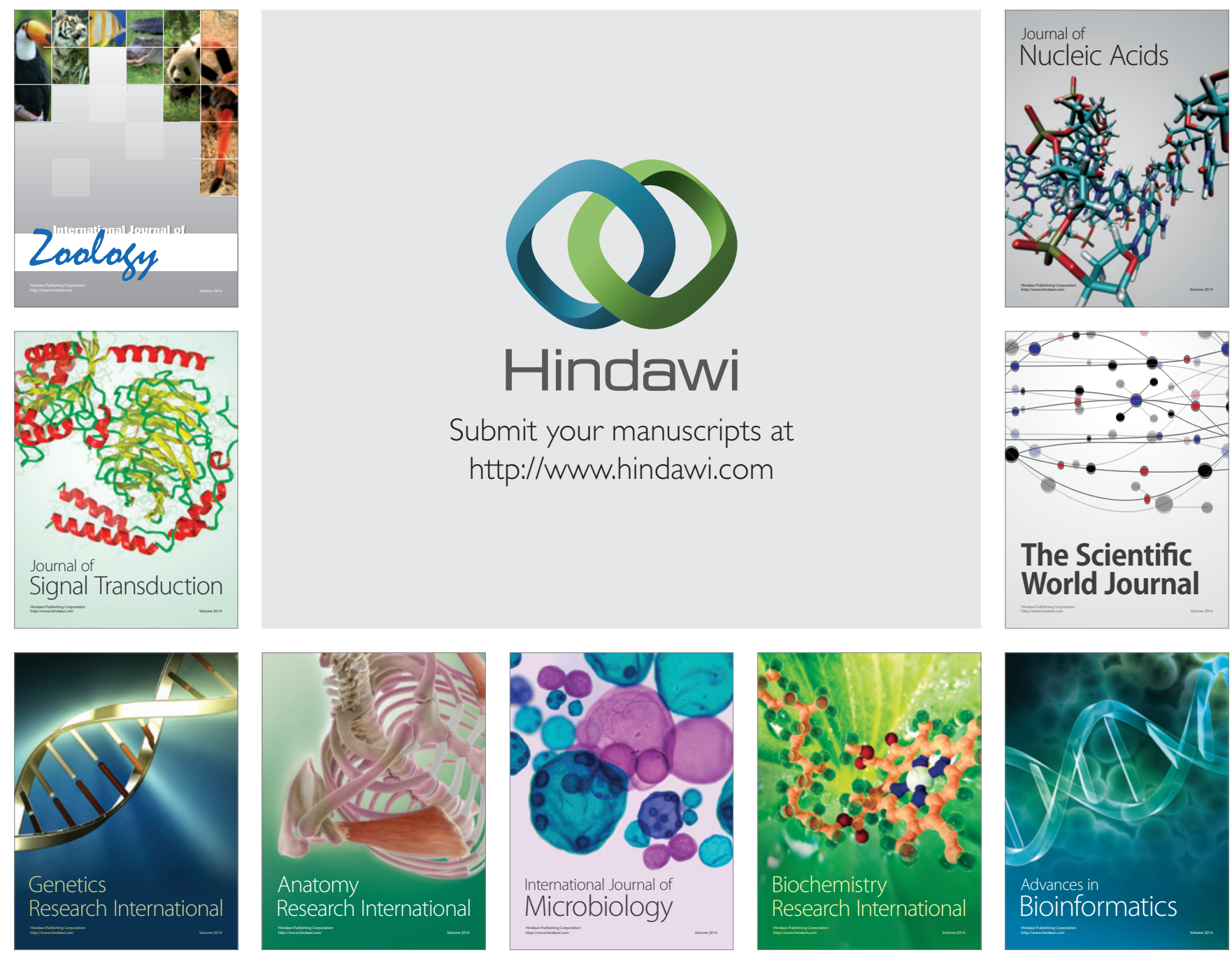

The Scientific World Journal
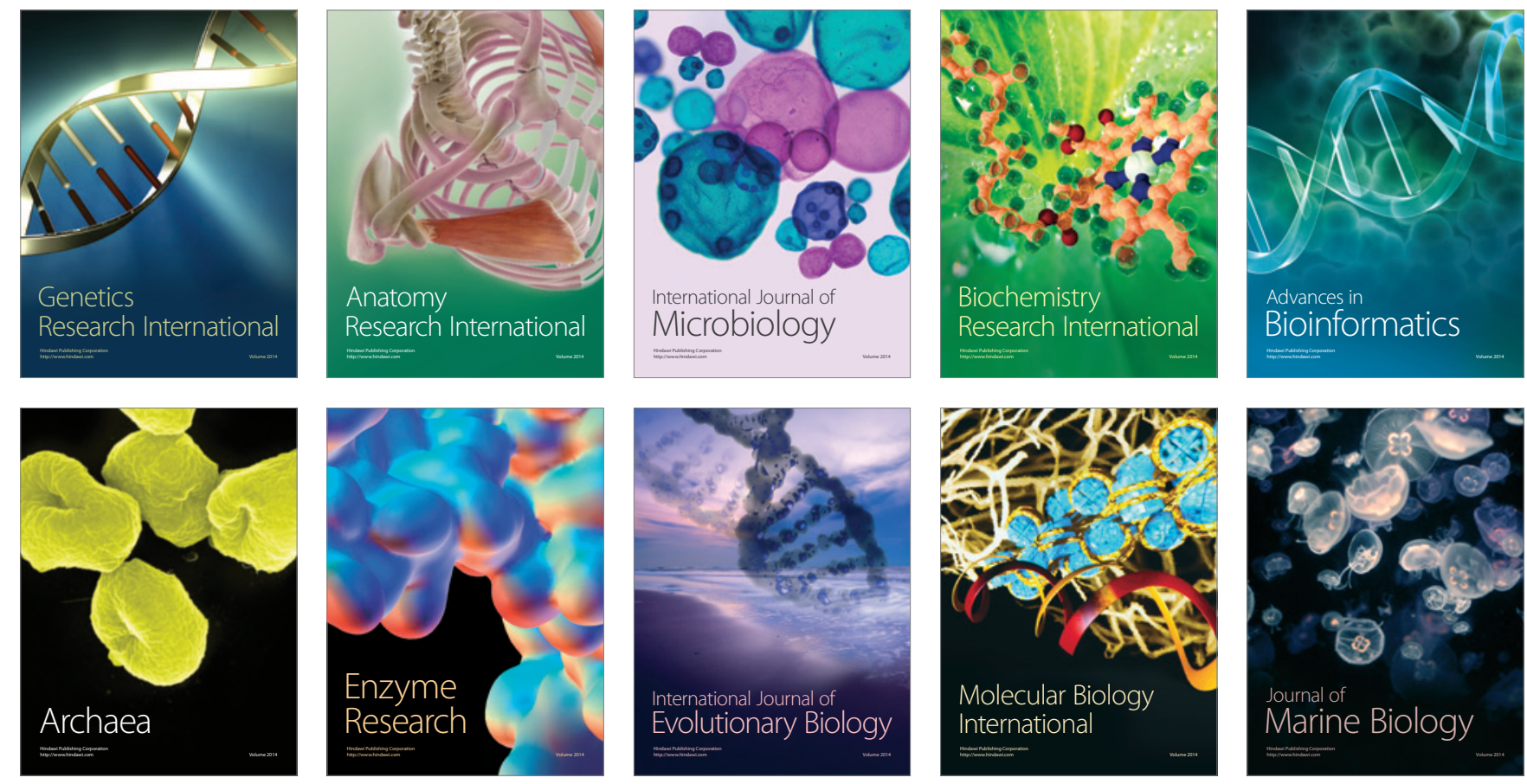